\title{
Assimilation and retention of selenium and other trace elements from crustacean food by juvenile striped bass (Morone saxatilis)
}

\author{
Stephen B. Baines and Nicholas S. Fisher \\ Marine Sciences Research Center, State University of New York, Stony Brook, New York 11794-5000
}

\section{Robin Stewart}

Water Resources Division, United States Geological Survey, Menlo Park, California 94025

\begin{abstract}
Estimates of the assimilation and retention of trace elements from food by fish are useful for linking toxicity with the biogeochemical cycling of these elements through aquatic food webs. Here we use pulse-chase radiotracer techniques to estimate the assimilation and retention of Se and four trace metals, $\mathrm{Ag}, \mathrm{Am}, \mathrm{Zn}$, and Cd, by 43- and 88-d-old juvenile striped bass, Morone saxatilis, from crustacean food. Brine shrimp nauplii, Artemia franciscana, or adult copepods, Acartia tonsa, were fed radiolabeled diatoms and then fed to juvenile striped bass. Assimilation efficiencies (AEs $\pm \mathrm{SD}$ ) for 43-d-old fish were $18 \pm 2 \%, 6 \pm 1 \%, 23 \pm 4 \%, 33 \pm 3 \%$, and $23 \pm 2 \%$ for $\mathrm{Ag}$, $\mathrm{Am}, \mathrm{Cd}, \mathrm{Se}$, and $\mathrm{Zn}$, respectively. For 88 -d-old fish, the AEs were $28 \pm 1 \%, 42 \pm 5 \%$, and $40 \pm 5 \%$ for $\mathrm{Cd}, \mathrm{Se}$, and $\mathrm{Zn}$, respectively. The higher AEs in the older fish may result from longer gut passage times for larger fish. The 44-d-old fish excreted $5 \pm 0.8 \%, 4 \pm 2.0 \%, 7 \pm 0.3 \%, 9 \pm 0.4 \%$, and $1.3 \pm 0.9 \%$ of the $\mathrm{Ag}, \mathrm{Am}, \mathrm{Cd}, \mathrm{Se}$, and $\mathrm{Zn}$, respectively, they ingested from food per day, whereas the 88 -d-old fish excreted $3 \pm 1.0 \%, 8 \pm 0.5 \%$, and $3 \pm 0.5 \%$ of the assimilated $\mathrm{Cd}, \mathrm{Se}$, and $\mathrm{Zn}$ per day, respectively. Predictions of steady state Se concentrations in juvenile striped bass tissues made using a biokinetic model and the measured AE and efflux rates ranged from 1.8 to $3.0 \mu \mathrm{g} \mathrm{Se} \mathrm{g}^{-1}$ dry wt for muscle tissue and 6.8 to $11.6 \mu \mathrm{g} \mathrm{Se} \mathrm{g}^{-1}$ dry wt for gut tissue. These predictions agreed well with average values of 2.1 and $13 \mu \mathrm{g} \mathrm{Se} \mathrm{g}^{-1}$ dry wt measured independently in North San Francisco Bay, where elevated Se concentrations are of concern. The model results imply that the planktonic food web, including juvenile striped bass, does not transfer Se as efficiently to top consumers as does the benthic food web.
\end{abstract}

The ability of fish to accumulate trace elements has received increasing attention in the last two decades as evidence of nutritional and toxicological effects mount (Luoma 1983). Se has generated particular interest because of its multiple roles as a potentially limiting nutrient in Se-deplete areas (Stadtman 1974), a toxic element in aquatic ecosystems affected by high Se in agricultural runoff and industrial wastes (Cutter 1989; Presser 1994; Presser et al. 1994), and a potential antagonist to $\mathrm{Hg}$ toxicity and accumulation (Wagemann et al. 1998). Along with $\mathrm{Hg}$ and $\mathrm{Cs}$, it is also one of the few trace elements subject to biomagnification (e.g., Luoma et al. 1992). Subtle changes in tissue concentrations of Se can have large effects on fish health. There is only a fourfold difference between tissue concentrations that are considered normal and those that can cause toxicity or teratogenesis in some species (Lemly 1998; Coughlin and Velte 1989).

An extensive literature shows that fish and other aquatic organisms obtain much of their body burden of Se and other trace elements from food (reviewed in Langston and Spence

\section{Acknowledgments}

We thank the Dennis Wildlife Center and Fish Hatchery in Bonneau, South Carolina, for donating the fish fry used in the experiment; M. Boda, F. Gallery, and E. Thomann for help in conducting the experiments and rearing and maintaining the fish; and D. Conover, T. Hurst, and S. Munch for advice in rearing the fish. Comments from M. Vanni and three anonymous reviewers improved the manuscript. This work was funded by grants from NSF (OCE9714308) and Calfed (B103). This is Contribution 1219 of the Marine Sciences Research Center.
1995; Reinfelder et al. 1998). Se found in tissues of fish is almost entirely derived from diet (Lemly 1982). Many other trace elements, including $\mathrm{Cd}, \mathrm{Co}, \mathrm{Mn}$, and $\mathrm{Zn}$, are also predominantly derived from ingested food by bivalves and copepods (e.g., Reinfelder and Fisher 1991; Wang et al. 1996; Wang and Fisher 1998a) and are readily assimilated from food by fish (e.g., Pentreath 1973a,b). Clearly, a predictive understanding of the variables affecting accumulation of $\mathrm{Se}$ and other trace elements from food by fish is needed to properly evaluate the biotic and ecosystem level effects of trace element contamination, and to accurately assess the viability of mitigating management strategies.

Toxicokinetic models provide a framework for developing such an understanding (Thomann 1981; Landrum et al. 1992). These models make steady state predictions of contaminant tissue concentrations based on several independently estimated parameters: growth, ingestion rate, element concentration in the food, assimilation efficiency for the element, and efflux rate (Table 1). Key to the successful application of the model is the accurate measurement of element assimilation efficiency and first-order efflux constants using radiotracer pulse-chase experiments (Reinfelder et al. 1998). Predictions of trace element concentrations in crustacean zooplankton and bivalves based on such measurements have agreed well with field data (Wang et al. 1996; Fisher et al. 2000; Roditi et al. 2000). Ultimately, by allowing us to couple information on the kinetics of trace element uptake and loss with bioenergetic models of consumption and growth, biokinetic models of trace element uptake may provide an effective framework for relating biological and 
Table 1. Summary of model parameter symbols.

\begin{tabular}{|c|c|c|}
\hline Symbol & Units & Description \\
\hline $\mathrm{AE}$ & $\%$ & $\begin{array}{l}\text { Assimilation efficiency: the percentage of an ingested element that is assimi- } \\
\text { lated into animal tissues }\end{array}$ \\
\hline $\mathrm{k}_{\mathrm{ef}}$ & $d^{-1}$ & Efflux constant of element obtained from food: fraction lost per day \\
\hline$g$ & $d^{-1}$ & Growth: instantaneous daily rate \\
\hline I & g dry wt $\mathrm{g}^{-1}$ dry wt $\mathrm{d}^{-1}$ & Ingestion rate \\
\hline $\mathrm{Se}_{\mathrm{x}}$ & $\mu \mathrm{g} \mathrm{Se} \mathrm{g}^{-1}$ dry wt & Concentration of target element per unit dry weight in pool $\mathrm{X}$ \\
\hline $\mathrm{CE}$ & $\%$ & $\begin{array}{l}\text { Conversion efficiency: the percentage of ingested food converted to biomass } \\
\text { by fish }\end{array}$ \\
\hline $\mathrm{A}, \mathrm{B}, \mathrm{C}$ & $\%$ & Estimates of initial element pool sizes in depuration experiments \\
\hline $\mathrm{k}_{\mathrm{A}}, \mathrm{k}_{\mathrm{B}}, \mathrm{k}_{\mathrm{C}}$ & $d^{-1}$ & Estimates of decay coefficients for element pools A, B, and C \\
\hline
\end{tabular}

environmental variables to trace element tissue concentrations. In this way, we can assess which trace elements, species, life stages, and environmental conditions are most important from either toxicological, biogeochemical, or nutritional perspectives.

There is a paucity of quantitative estimates of trace element assimilation efficiency and efflux for fish (Reinfelder et al. 1998). Such information on early life history stages would be especially useful because these stages often represent significant population survivorship bottlenecks. Furthermore, the early life history stages of many ecologically and commercially important fish species tend to be associated with coastal and estuarine habitats and are consequently exposed to high environmental contaminant levels during critical developmental periods. In this study, we measured the assimilation and loss of $\mathrm{Se}$ and several other trace elements from food by juvenile striped bass, Morone saxatilis. Striped bass are an economically and recreationally important anadromous fish that are common residents or immigrants into estuaries and rivers of North America. They are also sensitive to Se toxicity (Coughlin and Velte 1989).

In this study, we first compare trace element assimilation efficiencies and efflux constants measured for these fish using pulse-chase radioisotope experiments to those previously measured for invertebrates. We then determine if our laboratory measurements for Se are relevant to field conditions by comparing our steady state predictions of Se tissue concentrations to field measurements. Finally, we ask whether there is potential for present or future Se toxicity to striped bass based on our findings and whether the planktonic food web is as efficient a pathway for Se transfer as is the benthic pathway.

Table 2. Description of parameters for each experiment.

\begin{tabular}{lcc}
\hline \hline \multirow{2}{*}{ Variable } & \multicolumn{2}{c}{ Experiment } \\
\cline { 2 - 3 } & 1 & 2 \\
\hline Age of fish at start (d) & 43 & 88 \\
Food & Artemia franciscana & Acartia tonsa \\
No. of fish per replicate & $4-5$ & 1 \\
Mean weight of fish & & \\
$\quad$ (mg dry wt) & $11.8 \pm 4.7$ & $92.1 \pm 13$ \\
Mean length of fish (mm) & $19.6 \pm 2.3$ & $38.5 \pm 2.3$ \\
\hline
\end{tabular}

\section{Materials and methods}

Rearing of fish-Morone saxatilis larvae were obtained from the Dennis Wildlife Center Fish Hatchery in Bonneau, South Carolina, as 1-2-d-old hatchlings and reared at Flax Pond Marine Laboratory (Crane Neck, New York) in recirculating water tables. Rearing conditions are described elsewhere (Brown et al. 1998). Briefly, the larvae were maintained in freshwater that had been passed through an ion exchange column and then hardened to $>250 \mathrm{mg} \mathrm{HCO}_{3} \mathrm{~L}^{-1}$ by passing the water over crushed dolomite. Larvae were kept in indirect light and darkened buckets that were continuously flushed with water, except during feeding, from the recirculating water table. Temperatures ranged from 19 to $22^{\circ} \mathrm{C}$. Freshly hatched Artemia franciscana larvae (Argent Chemical, Silver grade) were used as forage throughout the experiment. Experiments were conducted on the fish when they were 43 and $88 \mathrm{~d}$ old (Table 2).

Experimental protocol-Seawater collected from the Flax Pond laboratory (salinity $=26$ ) was autoclaved and amended with f/2 nutrients excluding $\mathrm{Cu}, \mathrm{Zn}$, and EDTA (ethylenediamine tetraacetic acid) (Guillard and Ryther 1962). This water was then filtered through a sterile $0.2-\mu \mathrm{m}$ polycarbonate filter and corrected to $\mathrm{pH} 8.0$ with $\mathrm{NaOH}$, and 800 $\mathrm{ml}$ was dispensed into each of two 1-liter flasks. To one flask we added $9.3 \mathrm{kBq}$ of ${ }^{110 \mathrm{~m}} \mathrm{Ag}$ in $3 \mathrm{~N} \mathrm{HCl}$ and $37 \mathrm{kBq}$ of ${ }^{241} \mathrm{Am}$ in $6 \mathrm{~N} \mathrm{HNO}_{3}$. Another set of flasks received $74 \mathrm{kBq}$ of ${ }^{65} \mathrm{Zn}$ in $0.5 \mathrm{~N} \mathrm{HCl}, 37 \mathrm{kBq}$ of ${ }^{75} \mathrm{Se}$ (as selenite) in DI, and $222 \mathrm{kBq}$ of ${ }^{109} \mathrm{Cd}$ in $0.1 \mathrm{~N} \mathrm{HCl}$. In the second set of experiments, $148 \mathrm{kBq}$ of ${ }^{109} \mathrm{Cd}$ was added, while the amounts of ${ }^{65} \mathrm{Zn}$ and ${ }^{75} \mathrm{Se}$ added were the same as in the first experiment. The corresponding added concentrations in the first experiment were $1.3 \mathrm{nM} \mathrm{Ag}, 3.9 \mathrm{nM} \mathrm{Am}, 11.6 \mathrm{nM} \mathrm{Cd}, 0.42 \mathrm{nM}$ $\mathrm{Se}$, and $96 \mathrm{pM} \mathrm{Zn}$; in the second experiment, they were 1.4 $\mathrm{nM} \mathrm{Ag}, 3.9 \mathrm{nM}$ Am, $4.9 \mathrm{nM} \mathrm{Cd}, 0.54 \mathrm{nM}$ Se, and $0.12 \mathrm{nM}$ $\mathrm{Zn}$. The algal media with added radiolabeled trace elements were allowed to equilibrate for $24 \mathrm{~h}$ and then were inoculated (Fisher and Wente 1993) with log-phase cells of the diatom, Thalassiosira pseudonana (clone $3 \mathrm{H}$ ), to give an initial density of $1 \times 10^{5}$ cells $\mathrm{ml}^{-1}$. The cells were allowed to grow for $2 \mathrm{~d}$ to densities of $5-6 \times 10^{-5}$ cells $\mathrm{ml}^{-1}$.

Two sets of feeding experiments were conducted, one using Artemia franciscana larvae and the other using adults of 


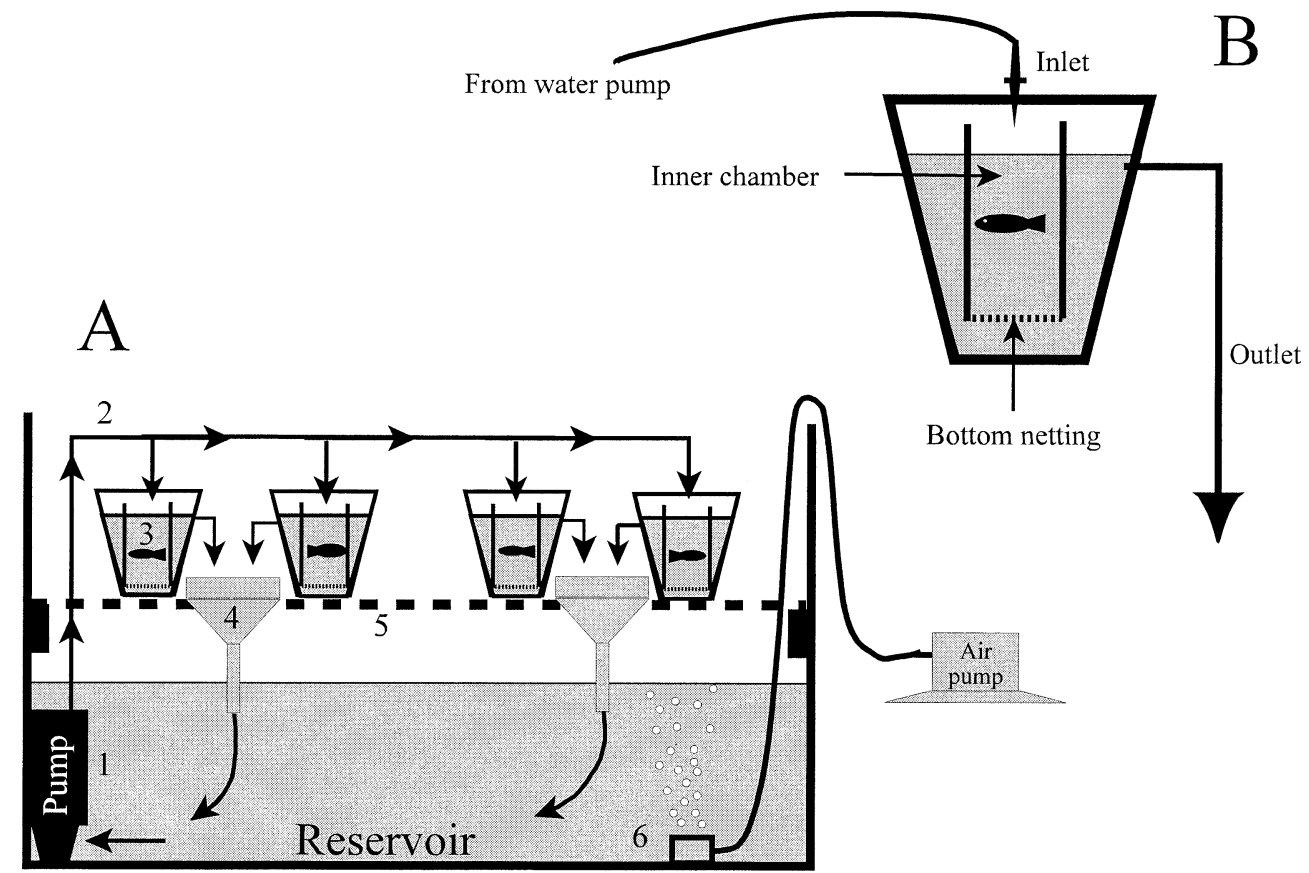

Fig. 1. Illustration of setup for the depuration experiments. (A) The experimental chambers. (B) The system for recirculating water through the experiments. 1, Powerhead water pump; 2, Tygon tubing for transferring water from the pump to the experimental chambers; 3 , experimental chamber; 4, funnel fitted with $60-\mu \mathrm{m}$ mesh Nitex netting; 5, plastic grating; 6, airstone.

the copepod, Acartia tonsa. The Artemia were hatched from cysts in the lab from the same stocks used to feed the fish. The copepods were handpicked from zooplankton net samples $(72 \mu \mathrm{m})$ taken from Stony Brook harbor. Approximately 2,000 1-d-old Artemia larvae or 800 A. tonsa adults were added to the flasks containing the labeled algae and allowed to feed for 16-24 h. Just prior to feeding these labeled zooplankton to the fish, the A. franciscana and A. tonsa were concentrated by gently pouring the contents of the flasks through a $100-\mu \mathrm{m}$ Nitex mesh and immediately resuspending in $100 \mathrm{ml}$ of filtered seawater.

The experimental apparatus for exposing the juvenile fish consisted of an 80-liter tank containing 20 liters of continuously recycled and bubbled $0.2-\mu \mathrm{m}$-filtered seawater that served to dilute radioisotope released during depuration, thus greatly reducing recycling (Fig. 1). Suspended above this filtered seawater reservoir on a plastic grating were chambers consisting of an outer 120-ml plastic container and an inner plastic cylinder closed at the top and bottom with fiberglass netting within which the fish were enclosed. This design further reduced recycling of radioisotope by allowing feces to fall through the netting and away from the fish. The chambers were cleaned prior to every time point by repeatedly decanting and flushing the chambers with fresh filtered seawater. This procedure greatly reduced mortality from stress associated with removing fish completely from the water. At most, one fish from each container died over the 3week experiments with the small fish. There was no mortality in the experiments with larger fish. Between counts, water from the 20-liter reservoir was continuously pumped into the central cylinder of each chamber. Fish were fed once daily by ceasing the water flow and adding freshly hatched Artemia larvae via pipette directly to the experimental chambers. After $1 \mathrm{~h}$, flow was resumed and the remaining Artemia were flushed out of the chambers and captured on $60-\mu \mathrm{m}$ nets before the water was returned to the reservoir. These nets were cleaned daily. There were four replicate chambers for each treatment.

An hour before the start of experiments, the netted plastic cylinders with fish were quickly removed from the experimental apparatus and placed in plastic sample containers containing $100 \mathrm{ml}$ of filtered Flax Pond water. Fish were allowed to acclimate for an hour to this setting. To initiate the experiment, the solution with concentrated Artemia and Acartia was first agitated to distribute the crustaceans randomly, after which a 20-ml aliquot was filtered onto a 100 $\mu \mathrm{m}$ mesh Nitex net, rinsed three times with filtered Flax Pond seawater, and then rinsed into the feeding containers. Fish were allowed to feed until they had eliminated $>95 \%$ of their prey within the netted plastic cylinders (i.e., $15 \mathrm{~min}$ for the Artemia/small fish experiment and $30 \mathrm{~min}$ for the Acartia/large fish experiment). After feeding, the cylinders containing the fish were removed from the feeding solution, passed quickly through three rinses of $0.2-\mu \mathrm{m}$-filtered Flax Pond water, and deposited into depuration containers containing filtered seawater for immediate gamma counting (see below). Immediately after the first gamma count, the fish were fed an excess of unlabeled Artemia for an hour. Previous experience showed that the fish filled their guts in this amount of time.

At each time point, feces were collected from the depuration chamber just prior to gamma counting. The chambers 
were decanted and flushed with $0.2-\mu \mathrm{m}$-filtered Flax Pond water repeatedly until little particulate material was remaining. Any remaining particles were removed by pipette and added to the decanted material. The decanted fluid was then filtered through a $0.2-\mu \mathrm{m}$ polycarbonate membrane, and the radioactivity of the filter was determined. If a fish had died during the prior sampling interval, it was also removed and analyzed. At the end of the depuration experiment, fish were sacrificed and dissected, and their radioactivity was assayed. Head, gut, and tail regions were separated and dried to constant weight at $60^{\circ} \mathrm{C}$. The dried tissues were then weighed and set aside for gamma counting.

Gamma radiation assays - Radioactivity associated with fish was determined in a $\mathrm{NaI}(\mathrm{Tl})$ deep-well gamma detector (Canberra). Fish were counted in their depuration chambers to reduce stress. To limit errors in gamma counting due to sample geometry relative to the detector, vertical movement of the fish within the chambers was limited by decanting all but the bottom $1 \mathrm{~cm}$ of water from the depuration chambers. $\mathrm{X}$-ray emissions of ${ }^{109} \mathrm{Cd}$ were assayed at $22-26 \mathrm{keV}$, whereas gamma emissions of ${ }^{241} \mathrm{Am},{ }^{75} \mathrm{Se}$, and ${ }^{65} \mathrm{Zn}$ were assayed at $60 \mathrm{keV}, 279 \mathrm{keV}$, and 1,115 keV, respectively. Gamma emissions of ${ }^{110 \mathrm{~m}} \mathrm{Ag}$ were at $657 \mathrm{keV}$ and $884 \mathrm{keV}$. Counting times were adjusted to yield $<5 \%$ analytical error or to a maximum time of $15 \mathrm{~min}$. All counts were corrected for blanks and spillover among isotopes. Radioactivity associated with feces, dead fish, and fish parts were counted with an intercalibrated $\mathrm{NaI}(\mathrm{Tl})$ well detector (Wallac-Pharmacia Compugamma) fitted with an autosampler.

Statistical analysis - Gut passage time (GPT) was operationally defined as the time needed to clear the guts of $95 \%$ of the ingested, unassimilated radioactivity. To determine this value, the radioactivity accumulated through time in fecal matter was regressed against time using the model $y=$ $y_{0}+\mathrm{a}\left(1-e^{-\mathrm{b} t}\right)+\mathrm{c} \cdot t$. The linear term $\mathrm{c} \cdot t$ accounts for the continuing presence of some radioactivity in fecal material after the main pulse of radioactivity has ended. This radioactivity probably reflects a small amount of re-adsorption of excreted radiotracer onto fecal particles. Consequently, only the term $y_{0}+\mathrm{a}\left(1-e^{-\mathrm{b} t}\right)$ is taken to reflect the defecation of the radiotracer pulse. The intercept, $y_{0}$, accounts for the delay between feeding and the initial production of radioactive feces. The equation predicts an asymptotic approach of $y$ over time to the maximum $\left(y_{0}+a\right)$. The GPT is thus the time needed for $y$ to reach $95 \%$ of this value. By substituting GPT $=0.95\left(\mathrm{a}+y_{0}\right)$ for $y$, we find that GPT $=$ $\ln \left[0.05\left(1+y_{0} \mathrm{a}^{-1}\right)\right] \mathrm{b}^{-1}$. Each replicate was analyzed separately, and the mean and standard deviation were determined from the replicate values.

Radioactivity in the depurating fish was regressed against time to determine the assimilation efficiencies (AE) and efflux constants for the isotopes assimilated from food $\left(\mathrm{k}_{\mathrm{ef}}\right)$. Either a two- or three-pool exponential decay model was used. In both cases, the assimilation efficiency is presumed equivalent to the size of the pool with the longest turnover time (see below). The decay coefficient for that pool is presumed to approximate the efflux constant. Data from each
Table 3. Parameters used to predict steady state Se tissue concentrations for juvenile striped bass feeding on San Francisco Bay zooplankton under low- and high-accumulation scenarios.

\begin{tabular}{|c|c|c|}
\hline Parameter & Low & High \\
\hline $\mathrm{AE}(\%)$ & & \\
\hline $\mathrm{k}\left(\% \mathrm{~d}^{-1}\right)$ & & \\
\hline $\mathrm{Se}_{\text {Muscle }}: \mathrm{Se}_{\text {Body }}$ & & \\
\hline $\mathrm{Se}_{\text {Liver }}: \mathrm{Se}_{\text {Body }}$ & & \\
\hline CE $(\%)$ & & \\
\hline $\mathrm{SE}_{\text {zoop }}\left(\mu \mathrm{g} \mathrm{Se}^{-1}\right.$ dry wt $)$ & 5 & 7 \\
\hline$g\left(\% \mathrm{~d}^{-1}\right)$ & 5 & 15 \\
\hline IR $\left(g g^{-1} d^{-1}\right)$ & 0.17 & 0.5 \\
\hline
\end{tabular}

replicate were analyzed separately, and the estimates of $\mathrm{AE}$ and $\mathrm{k}_{\mathrm{ef}}$ were averaged.

Model validation-Estimates of steady state Se tissue concentration in juvenile striped bass were made according to the equation $\mathrm{Se}_{\mathrm{ss}}=\mathrm{AE} \cdot \mathrm{IR} \cdot \mathrm{Se}_{\mathrm{f}} /\left(g+\mathrm{k}_{\mathrm{ef}}\right)$, where $g$ is the dry weight-specific growth rate $\left(\mathrm{d}^{-1}\right), \mathrm{Se}_{\mathrm{ss}}$ is the steady state $\mathrm{Se}$ concentration in fish tissues ( $\mathrm{g} \mathrm{Se} \mathrm{g}^{-1}$ dry wt), $\mathrm{Se}_{\mathrm{f}}$ is the $\mathrm{Se}$ concentration in food ( $\mathrm{g} \mathrm{Se}^{-1}$ dry wt), and IR is the ingestion rate (g dry wt $\mathrm{g}^{-1}$ dry $w \mathrm{w} \mathrm{d}^{-1}$ ). This equation ignores the effect of Se absorbed directly from the dissolved phase, which is generally negligible in marine animals (Wang et al. 1996; Wang and Fisher 1998a). The values used in the calculation are presented in Table 3. AE and $\mathrm{k}_{\mathrm{ef}}$ values for the large fish were used. A minimum $\mathrm{Se}_{\mathrm{f}}$ was assumed to be equivalent to $5 \mu \mathrm{g} \mathrm{Se}^{-1}$ dry wt based on measurements of mixed zooplankton communities $(73-3,000-\mu \mathrm{m}$ size fraction) from Suisun Bay, San Francisco Bay (M. Doblin et al. pers. comm.). Stable isotope analyses indicate that juvenile striped bass in San Francisco Bay feed heavily on mysid shrimp (R. Stewart unpubl. data). There are no extant data on Se contents in mysids in San Francisco Bay, but recent work indicates that mysids should possess Se tissue concentrations, at most, 1.4-fold higher than their zooplankton prey based on measured $\mathrm{AE}$ and $\mathrm{k}_{\mathrm{ef}}$ (C. Schlekat pers. comm.). Consequently, we used $7 \mu \mathrm{g} \mathrm{Se}^{-1}$ dry wt as a maximum estimate of $\mathrm{Se}_{\mathrm{f}}$.

A range of ingestion rates was calculated assuming high and low accumulation scenarios. Maximal weight-specific growth rates for young ( $0-28 \mathrm{~d})$ juvenile striped bass range from 0.12 to $0.2 \mathrm{~d}^{-1}$ depending on latitude of the source population and temperature (Conover et al. 1997). For the high-growth scenario, we adopted $0.15 \mathrm{~d}^{-1}$ because it is typical of maximal growth rates for striped bass larvae and juveniles in low-midtemperate waters at $20-25^{\circ} \mathrm{C}$ (Conover et al. 1997; Brown et al. 1998). For the low-growth scenario, we arbitrarily chose a rate $1 / 3$ of the high-growth scenario. To calculate ingestion (IR), we assumed a gross conversion efficiency (CE, the ratio between biomass production and ingestion) of 0.30 . This $\mathrm{CE}$ was determined by fitting the University of Wisconsin fish bioenergetics model (S. W. Hewitt and B. L. Johnson, University of Wisconsin Sea Grant Institute) to juvenile wet weights for fish sampled from San Francisco Bay in September (see below) assuming the fish were hatched in mid-March (Heubach et al. 1963) 
and using seasonal temperature data for Alameda, California (NOAA, National Oceanic Data Center), and bioenergetic parameters from Moore (1988). We can calculate IR under the fast and slow growth scenarios according to the steady state equation IR $=g / \mathrm{CE}$. We estimated Se concentrations in gut and tail portions of the fish by multiplying the wholefish Se tissue concentration by the average relative tissue concentration of Se in the gut and tail.

High (high IR, high $\mathrm{Se}_{\mathrm{f}}$ ) and low (low IR, low $\mathrm{Se}_{\mathrm{f}}$ ) predictions of Se tissue concentrations in young juvenile striped bass were compared to concentrations measured in liver and muscle of 13 juvenile ( $\sim 6$ months) striped bass collected from Suisun Bay on 30 September 1999 and in 15 adult striped bass collected from San Pablo Bay ( $n=7,7$ December 1999) and Suisun Bay ( $n=8,17$ December 1999). Analysis of Se was by hydride generation after total digestion in concentrated nitric and perchloric acids at $200^{\circ} \mathrm{C}$ and reconstitution in hydrochloric acid. Recoveries of total Se in reference materials were within the accepted range for the materials (CRC Dorm2: $1.4 \pm 0.1$ [measured, $n=6$ ], $1.4 \pm$ 0.1 [accepted]; CRC Dolt2: $5.8 \pm 0.3$ [measured, $n=7$ ], $6.1 \pm 0.5$ [accepted]; CRC Tort2: $5.2 \pm 0.3$ [measured, $n$ $=6], 5.6 \pm 0.7$ [accepted]).

\section{Results}

Following consumption of radiolabeled Artemia franciscana, the radioactivity in $M$. saxatilis was $10.6 \mathrm{~Bq}{ }^{241} \mathrm{Am}$, $6.7 \mathrm{~Bq}{ }^{110 m} \mathrm{Ag}, 47.5 \mathrm{~Bq}{ }^{109} \mathrm{Cd}, 65.2 \mathrm{~Bq}{ }^{75} \mathrm{Se}$, and $53.6 \mathrm{~Bq}{ }^{65} \mathrm{Zn}$ per experimental replicate. In the experiment with Acartia tonsa, each fish ingested $0.9 \mathrm{~Bq}{ }^{109} \mathrm{Cd}, 10.5 \mathrm{~Bq}{ }^{75} \mathrm{Se}$, and 4.7 ${ }_{\mathrm{Bq}}{ }^{65} \mathrm{Zn}$. The experiments did not expose the fish to a large pulse of trace elements relative to background. In the first experiment, the uptake of label and carrier by the fish increased their overall tissue concentration relative to dry weight by $6 \mathrm{ng} \mathrm{g}^{-1}$ dry wt for $\mathrm{Cd}, 3 \mathrm{ng} \mathrm{g}^{-1}$ dry wt for $\mathrm{Zn}$, and $<2 \mathrm{ng} \mathrm{g}^{-1}$ dry wt for $\mathrm{Se}, \mathrm{Ag}$, and $\mathrm{Am}$. In the second experiment, the increase for all trace elements was less than $1 \mathrm{ng} \mathrm{g}^{-1}$ dry wt. For $\mathrm{Cd}, \mathrm{Zn}, \mathrm{Se}$, and $\mathrm{Ag}$, these values are substantially less than typical tissue residues observed for fish in undisturbed environments (Kennish 1996). Consequently, we believe our results best represent trace element processing by juvenile striped bass when ambient trace element concentrations are near natural background levels. Se in the zooplankton of marine portions of San Francisco Bay is only two to three times more concentrated than in the zooplankton of other uncontaminated environments (M. Doblin unpubl. data).

All radioisotopes in the fish declined with time (Figs. 2, 3). After an initial period of minimal loss of radiotracer, two distinct phases of depuration were apparent. The first was a period of rapid decline that corresponded to the production of highly radioactive feces. We interpret this phase as primarily due to defecation of unassimilated radioisotope. After 24-36 $\mathrm{h}$, radioactivity in feces was at low or background concentrations, and loss of radioisotope from the fish slowed significantly. The loss of radioactivity after $36 \mathrm{~h}$ is presumed to correspond to excretion of assimilated radioisotope. Loss of radioisotope from fish in both egestion and excretion

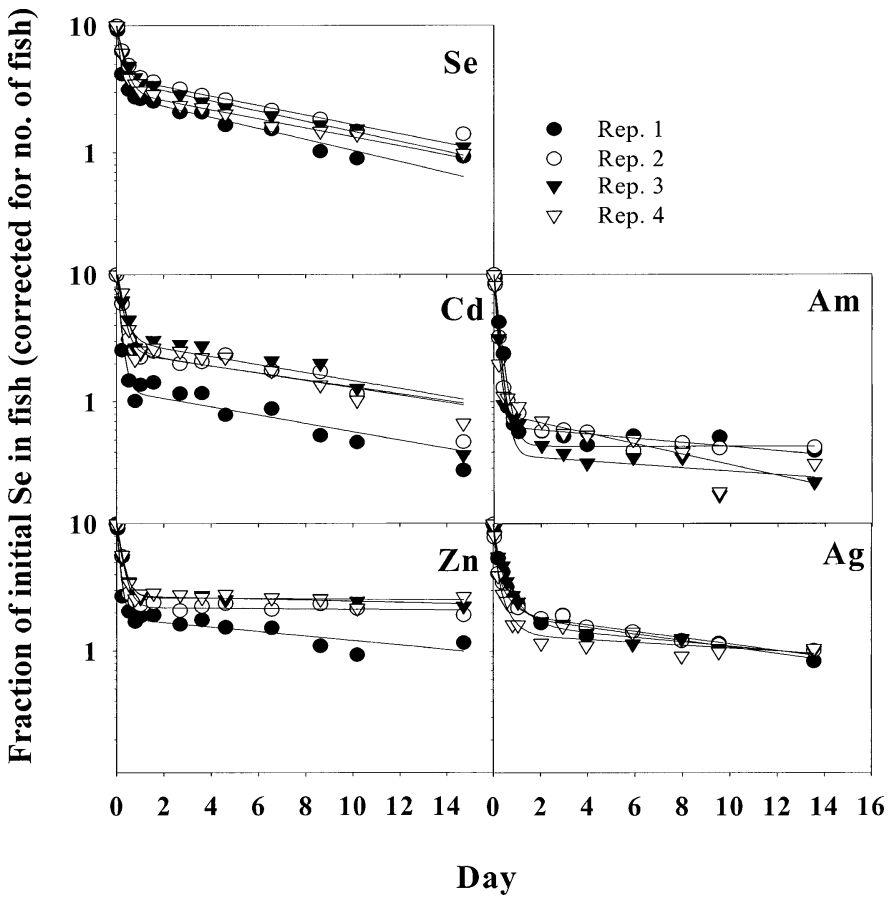

Fig. 2. Loss of ${ }^{75} \mathrm{Se},{ }^{109} \mathrm{Cd},{ }^{65} \mathrm{Zn},{ }^{241} \mathrm{Am}$, and ${ }^{110 \mathrm{~m}} \mathrm{Ag}$ from $43-\mathrm{d}-$ old M. saxatilis-fed radiolabeled Artemia franciscana. Each point represents a single experimental chamber holding two to five individuals. Radioactivity is normalized to the number of fish alive in the chambers at the time of measurement. The lines represent best fit exponential decay models of two or three compartments (see text). Regression lines are fitted to each replicate separately.

phases approximately followed first-order decay kinetics (Figs. 2, 3). Two-pool exponential decay models were sufficient to explain $>90 \%$ of the observed variance (adjusted $\left.r^{2}\right)$ in radiotracer loss from the fish for ${ }^{75} \mathrm{Se}(98-99 \%),{ }^{65} \mathrm{Zn}$ (92-98\%), ${ }^{109} \mathrm{Cd}(90-96 \%)$, and ${ }^{241} \mathrm{Am}(95$ to $>99 \%$ ) (Table 4). However, a three-pool model was necessary to explain the data for ${ }^{110 \mathrm{~m}} \mathrm{Ag}$ (adjusted $r^{2}>99 \%$ ). Two of the pools in the $\mathrm{Ag}$ model displayed turnover times $<1 \mathrm{~d}$ (i.e., efflux rate constants of $>100 \% \mathrm{~d}^{-1}$ ), so we presume these two pools correspond to some partitioning of unassimilated material. Consequently, the slow third pool was used to estimate $\mathrm{AE}$ and $\mathrm{k}_{\mathrm{ef}}$ for $\mathrm{Ag}$.

Se was the element most efficiently assimilated from food by both small and large fish, although the difference from Cd was borderline insignificant for the small fish $(P=0.06$, two-tailed $t$-test), and the difference from $\mathrm{Zn}$ was insignificant in the large fish $(P=0.79$, two-tailed $t$-test $)$ (Table 4$)$. Am was the least efficiently assimilated element in all cases. $\mathrm{Ag}$ was assimilated at efficiencies greater than Am and less than $\mathrm{Cd}$ and $\mathrm{Zn}$, but the latter differences were not significant $(P=0.24$ and 0.06 , respectively). The ranking of elements with regard to $\mathrm{AE}$ was $\mathrm{Se}>\mathrm{Zn}=\mathrm{Cd}>\mathrm{Ag}>\mathrm{Am}$ for the small fish and $\mathrm{Se}=\mathrm{Zn}>\mathrm{Cd}$ for the large fish. Se $(P=0.05$, two-tailed $t$-test $)$ and $\mathrm{Zn}(P=0.01)$ were assimilated more efficiently by the large fish, but $\mathrm{Cd}$ assimilation did not differ appreciably between the two sizes of fish.

There were systematic differences in the rate of efflux $\left(\mathrm{k}_{\mathrm{ef}}\right)$ for the elements studied. With the exception of Am, for 


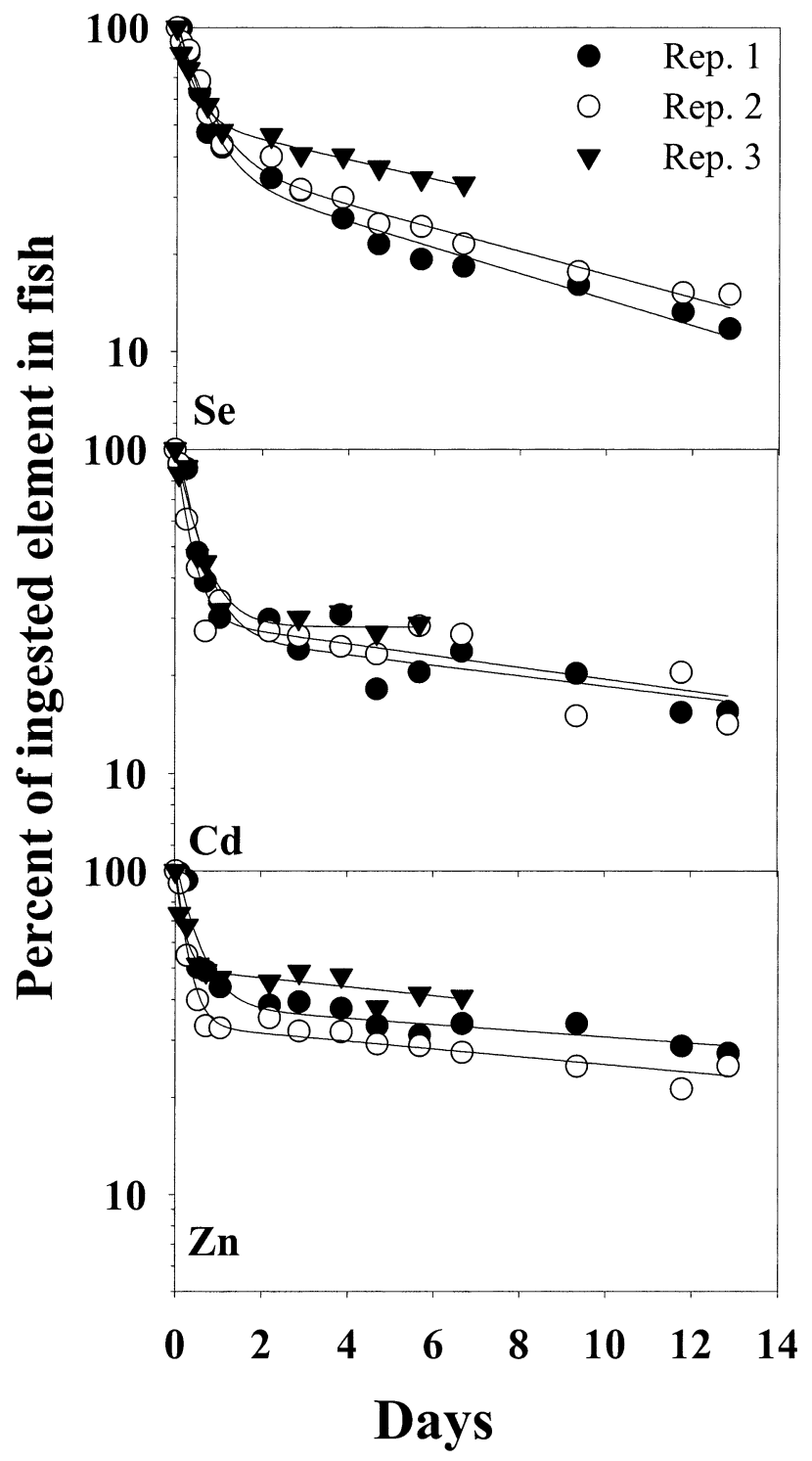

Fig. 3. Loss of ${ }^{75} \mathrm{Se},{ }^{109} \mathrm{Cd}$, and ${ }^{65} \mathrm{Zn}$ from 88 -d-old $M$. saxatilis fed radiolabeled Acartia tonsa. Each point represents a single experimental chamber holding one individual. The lines represent best fit exponential decay models of two compartments (see text). The lines are fitted to each replicate separately.

which estimates of $k_{\text {ef }}$ were extremely variable, efflux rates were significantly higher for Se than for the other elements in both large and small fish (Table 4). Between 8 and $10 \%$ of the assimilated Se was lost per day. In contrast, $\mathrm{Zn}$ was always retained the most with loss rates averaging 1.5 and $2.5 \% \mathrm{~d}^{-1}$ over the two experiments. Values for Am, Ag, and $\mathrm{Cd}$ tended to be intermediate between these extremes. Small fish excreted $\mathrm{Cd}$ at a twofold greater rate than did large fish, whereas $\mathrm{Se}$ and $\mathrm{Zn}$ efflux rates were not distinguishable between large and small fish.

The model used to fit the cumulative fecal matter production data explained $>96 \%$ of the variance in every case. Estimates of GPT were $<24 \mathrm{~h}$ for the small fish and ranged from $11 \mathrm{~h}$ for Am to $22.5 \mathrm{~h}$ for $\mathrm{Cd}$ (Table 5). The Se and
Zn GPTs were $17 \mathrm{~h}$ for the small fish, but increased to $29 \mathrm{~h}$ and $35 \mathrm{~h}$, respectively, for the large fish. The GPT for Cd was actually shorter for the large fish than the small fish, but not significantly so because of the wide variability of the GPT estimates for Cd. GPT could predict AE effectively when data for all elements and sizes were combined (Fig. 4; model: $\mathrm{AE}=y_{0}+\mathrm{b} \log (\mathrm{GPT})$, adjusted $r^{2}=0.61, P=$ $0.01)$.

$\mathrm{Cd}, \mathrm{Se}$, and $\mathrm{Zn}$ differed markedly in their distributions (relative to the whole body) within the fish at the end of the depuration experiment (Fig. 5). Of the $\mathrm{Cd}$ in the fish, 70\% was located in the tail, $20 \%$ in the gut, and $10 \%$ in the head. Se and $\mathrm{Zn}$ were both primarily associated with the head (55$63 \%$ ), with about $33-34 \%$ being in the tail. Only $4 \%$ of the $\mathrm{Zn}$ and $11 \%$ of the Se was found in the gut. Although the gut was not important in the inventory of the elements we studied, trace element concentrations were considerably greater there. Cd and Se were 4.4 and 2.5 times more concentrated in the gut on a dry weight basis than in the body as a whole. In other ways, concentrations of Se and Cd differed among body parts. Se was 1.2 times more concentrated in the head than in the whole body, whereas the Cd concentration in the head was only $18 \%$ of that in the whole body. The reverse was true of concentrations of these elements in the tail, where $\mathrm{Cd}$ was more concentrated $(1.3 \times)$ and Se less concentrated $(0.6 \times)$ than in the body. $\mathrm{Zn}$ was more evenly distributed throughout the body than were the other two elements. Moreover, $\mathrm{Zn}$ was unique in being more concentrated in the head $(1.5 \times)$ than in the tail $(0.6 \times)$ or gut $(0.8 \times)$. Insufficient $\mathrm{Am}$ and $\mathrm{Ag}$ was left in the fish at the end of the depuration phase to determine the tissue distributions of those metals.

Steady state concentrations of Se in striped bass gut and tail tissue predicted with the kinetic model under slow and fast growth scenarios bracketed the mean values measured independently for liver and muscle tissue from striped bass captured from San Francisco Bay (Fig. 6). Concentrations of $\mathrm{Se}$ in tail tissues of juvenile striped bass surviving on a diet of zooplankton were predicted to vary from 1.8 to $3.0 \mu \mathrm{g}$ Se $\mathrm{g}^{-1}$ dry wt as growth increased from $0.05 \mathrm{~d}^{-1}$ to $0.15 \mathrm{~d}^{-1}$ and ingestion increased from 0.17 to $0.5 \mathrm{~g}$ dry $\mathrm{wt}^{-1}$ dry wt $\mathrm{d}^{-1}$. Predicted concentrations in gut tissues over the same range in growth and ingestion rate ranged from 6.8 to 11.6 $\mu \mathrm{g} \mathrm{Se}^{-1}$ dry wt. Se tissue concentrations in San Francisco Bay juvenile striped bass muscle and liver tissue averaged 2.1 and $13 \mu \mathrm{g} \mathrm{Se}^{-1}$ dry wt, respectively.

Sensitivity of Se tissue concentration predictions to variability in $\mathrm{CE}, \mathrm{AE}, \mathrm{IR}$, and $\mathrm{Se}_{\mathrm{f}}$ was deemed unnecessary because all of these predictors are directly or inversely proportional to the predictions. However, the predictions are mildly nonlinearly related to $\mathrm{k}_{\mathrm{ef}}$ in a manner dependent on the value of $g$. Under the slow-growth scenario, when $g=$ $5 \% \mathrm{~d}^{-1}$, a $10 \%$ increase or decrease in $\mathrm{k}_{\text {ef }}$ results in a $6 \%$ decrease or a $7 \%$ increase in $\mathrm{Se}_{\mathrm{ss}}$, respectively. Under the fast-growth scenario, when $g=15 \% \mathrm{~d}^{-1}$, the same numbers are only 3.5 and $3.8 \%$.

\section{Discussion}

The relative differences observed in the assimilation and retention of the different trace elements agree well with what 
Table 4. Mean depuration model parameters. Data from each replicate were fit to either a two- or three-pool first-order exponential decay model. A and B represent percentage of ingested radiotracer in pools primarily associated with the unassimilated material in the gut and subject to fast turnover through defecation. The constants $\mathrm{K}_{\mathrm{A}}$ and $\mathrm{k}_{\mathrm{B}}$ are the first-order decay constants for those pools. $\mathrm{C}$ is the percentage of ingested material that is assimilated (AE), and $k_{c}$ is equivalent to the efflux constant $\left(\mathrm{k}_{\mathrm{ef}}\right)$. $T b_{1 / 2}$ is the biological half-life of assimilated elements. Values represent the means of regression coefficients from four (small fish) or three (large fish) replicates \pm 1 SE.

\begin{tabular}{|c|c|c|c|c|c|c|c|c|}
\hline Fish & Element & A $(\%)$ & $\mathrm{k}_{\mathrm{A}}\left(\mathrm{d}^{-1}\right)$ & B $(\%)$ & $\mathrm{k}_{\mathrm{B}}\left(\mathrm{d}^{-1}\right)$ & $\mathrm{C}(\%)$ & $\mathrm{k}_{\mathrm{C}}\left(\mathrm{d}^{-1}\right)$ & $\mathrm{Tb}_{1 / 2}(\mathrm{~d})$ \\
\hline Small & $\mathrm{Ag}$ & $44 \pm 6$ & $8.9 \pm 1.0$ & $39 \pm 6$ & $2.1 \pm 0.2$ & $18 \pm 1.5$ & $0.05 \pm 0.008$ & 13.9 \\
\hline Small & $\mathrm{Am}$ & $94 \pm 1$ & $5.7 \pm 0.8$ & & & $6 \pm 1$ & $0.04 \pm 0.02$ & 17.3 \\
\hline Small & $\mathrm{Cd}$ & $77 \pm 4$ & $3.5 \pm 0.6$ & & & $23 \pm 4$ & $0.07 \pm 0.003$ & 9.9 \\
\hline Small & $\mathrm{Se}$ & $67 \pm 3$ & $3.7 \pm 0.6$ & & & $33 \pm 3$ & $0.09 \pm 0.004$ & 7.3 \\
\hline Small & $\mathrm{Zn}$ & $77 \pm 2$ & $4.3 \pm 0.7$ & & & $23 \pm 2$ & $0.013 \pm 0.009$ & 53.3 \\
\hline Large & $\mathrm{Cd}$ & $72 \pm 1$ & $2.2 \pm 0.4$ & & & $28 \pm 1$ & $0.03 \pm 0.01$ & 23.1 \\
\hline Large & $\mathrm{Se}$ & $58 \pm 5$ & $2.0 \pm 0.5$ & & & $42 \pm 5$ & $0.08 \pm 0.005$ & 8.7 \\
\hline Large & $\mathrm{Zn}$ & $60 \pm 5$ & $3.6 \pm 1.0$ & & & $40 \pm 5$ & $0.03 \pm 0.004$ & 23.1 \\
\hline
\end{tabular}

has been observed in previous studies on two species of silversides (Reinfelder and Fisher 1994). However, the absolute value for Se AE was slightly higher than measured for Menidia feeding on copepods (33-40\% compared to $29 \%$ ), and AEs for $\mathrm{Zn}$ and $\mathrm{Cd}$ were much higher in the present study (23-48\% and 23-40\% compared to 6 and 3\%, respectively). Although assimilation of $\mathrm{Ag}$ and Am have not been studied in fish per se, the lower assimilation of these elements, and Am in particular, agrees well with studies of assimilation by benthic bivalves feeding on phytoplankton and radiolabeled seston (Wang et al. 1996; Roditi and Fisher 1999) and for copepods feeding on phytoplankton (Wang and Fisher 1998a). The observed ranking of metals in terms of assimilability is consistent with the findings of Reinfelder and Fisher (1991), which indicated that AE for an element is directly related to the tendency for that element to be associated with the cytoplasm of cells.

The difference in AEs observed for $\mathrm{Zn}, \mathrm{Cd}$, and Se in this study and that of Reinfelder and Fisher (1994) probably stem from differences in the partitioning of these elements into dissolved internal pools and exoskeleton of the crustaceans. To mimic the condition of high particle load prevalent in estuaries, suspended particle concentrations during the labeling of the crustaceans were much higher in our experiments than in the Menidia experiments. Concentrations of

Table 5. Gut passage times (GPTs) for the five trace elements in the experiments with small and large fish. GPT is equivalent to the time needed for $95 \%$ of the defecation to take place. Cumulative radioactivity collected as feces was regressed against time according to the model $y=y_{0}+\mathrm{a}\left(1-e^{-\mathrm{b} t}\right)+\mathrm{c} t$. GPT was calculated from the regression coefficients as $\ln \left[0.05\left(1+y_{0}\right.\right.$ a) $] /-\mathrm{b}$ (see text). Values are the means of four groups of four to five fish for the small fish experiment and three fish for the large fish experiment $\pm 1 \mathrm{SD}$. nd, not determined.

\begin{tabular}{lcc}
\hline \hline & \multicolumn{2}{c}{ Gut passage time (h) } \\
\cline { 2 - 3 } Element & Small fish & Large fish \\
\hline $\mathrm{Ag}$ & $13.0 \pm 3.6$ & nd \\
$\mathrm{Am}$ & $11.1 \pm 0.7$ & nd \\
$\mathrm{Cd}$ & $22.5 \pm 4.5$ & $14.0 \pm 2.9$ \\
$\mathrm{Se}$ & $17.0 \pm 2.1$ & $28.6 \pm 5.2$ \\
$\mathrm{Zn}$ & $17.0 \pm 2.0$ & $39.8 \pm 3.1$ \\
\hline
\end{tabular}

algae were approximately five- to sixfold higher in our ex-

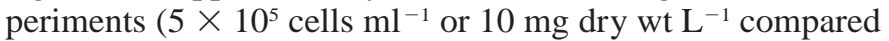
to $1 \times 10^{5}$ cells $\mathrm{ml}^{-1}$ or $2 \mathrm{mg}$ dry $\mathrm{wt} \mathrm{L}^{-1}$ ) at the initiation of feeding. Consequently, the fraction of total $\mathrm{Zn}$ and $\mathrm{Cd}$ on algal cells in the suspensions used to label the crustaceans was about $48-65 \%$ and $13-15 \%$, respectively (compared to 24 and 1\%). Thus, in our experiments, the direct adsorption of these metals onto external exoskeletons was probably reduced significantly, whereas the uptake of the metals internally by ingestion of algae was probably enhanced. We believe the combined effect was to decrease the fraction of accumulated $\mathrm{Zn}$ and $\mathrm{Cd}$ that was adsorbed onto the exoskeleton and, therefore, increase the assimilability of these metals from crustaceans by the fish. Se, by contrast, was little affected by particle loads because it does not adsorb onto cell walls or exoskeletons in seawater but is actively incorporated into cytoplasm (Fisher and Reinfelder 1991). The differences in AE between our study and that of Reinfelder and Fisher (1994) indicate how high particle loads in estuaries can alter not only the gross flux of trace elements into the food web, but the pathways of that flux and the

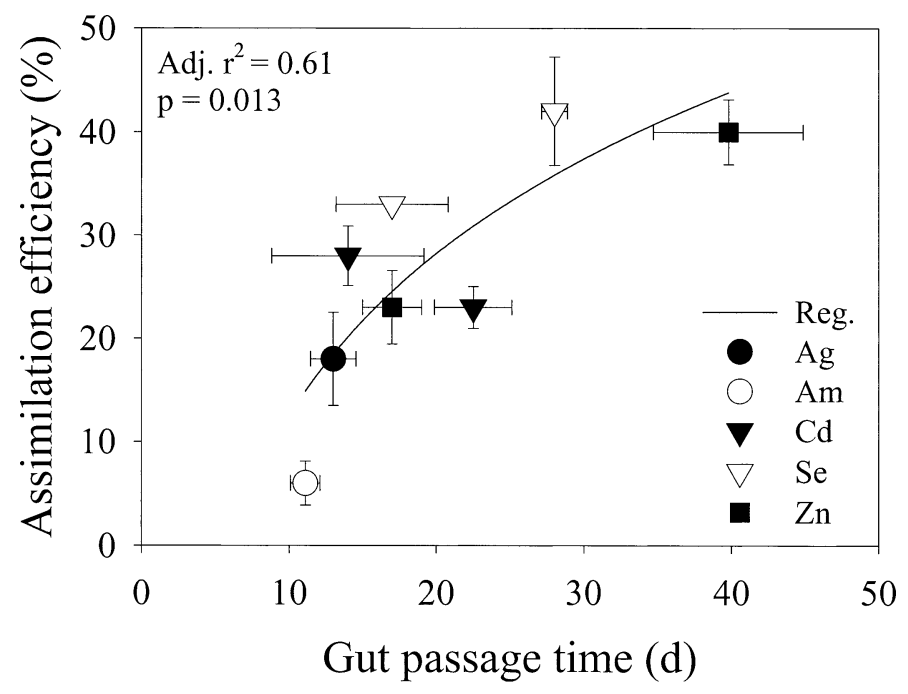

Fig. 4. Correlation between gut passage time (GPT) and AE for all ages of fish and all elements. The regression line represents the equation $\mathrm{AE}=\mathrm{a}\left(1-e^{-\mathrm{b} \cdot \mathrm{GPT}}\right)$. Error bars are $\pm 1 \mathrm{SD}$. 

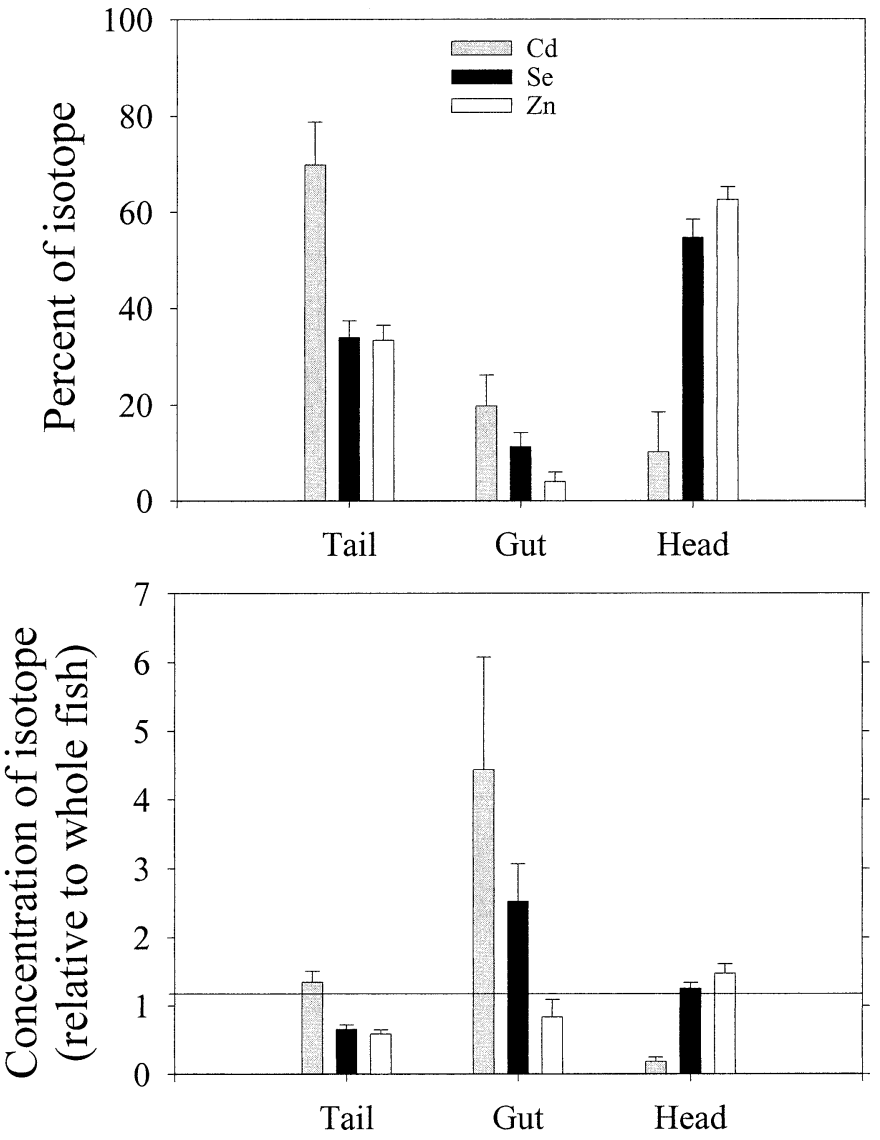

Fig. 5. Distribution of ${ }^{75} \mathrm{Se},{ }^{109} \mathrm{Cd}$, and ${ }^{65} \mathrm{Zn}$ within 43 -d-old $M$. saxatilis fed radiolabeled Artemia franciscana. The top panel represents the fraction of radioactivity associated with each radioisotope in each body part. The lower panel shows the concentration of radioactivity associated with each isotope relative to dry weight. Bars are the means of $14-15$ fish. Error bars are \pm 1 SD.

consequent efficiency of transport of trace elements up food webs.

The ranking of $\mathrm{AEs}$ for $\mathrm{Am}, \mathrm{Ag}, \mathrm{Cd}, \mathrm{Se}$, and $\mathrm{Zn}$ for striped bass were almost identical to those observed for bivalves and copepods, whereas the absolute values were either comparable or somewhat lower. They seem particularly low relative to estimates of AE for several marine bivalves fed on pure algae, which ranged from 3 to $40 \%$ for Am, 13 to $44 \%$ for $\mathrm{Ag}, 37$ to $83 \%$ for $\mathrm{Cd}, 70$ to $92 \%$ for $\mathrm{Se}$, and 62 to $73 \%$ for $\mathrm{Zn}$ (Reinfelder et al. 1997). However, the values for Mytilus edulis fed on radiolabeled seston were more comparable to our results: $4-34 \%$ for $\mathrm{Ag}, 11-40 \%$ for Cd, 15-72\% for Se, and 16-48\% for Zn (Wang et al. 1996). By comparison, $\mathrm{AEs}$ of $\mathrm{Ag}, \mathrm{Cd}, \mathrm{Se}$, and $\mathrm{Zn}$ for the copepod Temora longicornis fed on algae were 13, 35, 59, and $61 \%$, respectively.

The efflux rates of metals from the juvenile striped bass were generally higher than those from various bivalve species but lower than from marine copepods. The $\mathrm{k}_{\mathrm{ef}} \mathrm{s}$ in bivalves for a range of elements generally vary between 1 and 5\% $\mathrm{d}^{-1}$ (Fisher et al. 1996; Reinfelder et al. 1997; Roditi and Fisher 1999). By contrast, the $\mathrm{k}_{\mathrm{ef}} \mathrm{s}$ in juvenile striped bass ranged almost sevenfold between $\mathrm{Zn}$ and $\mathrm{Se}$, and all

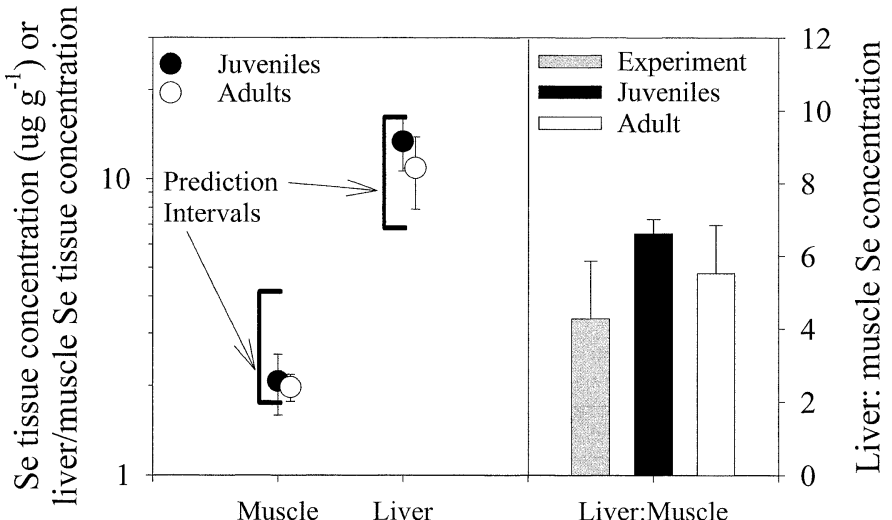

Fig. 6. Comparison of observed and model-predicted Se concentrations in $M$. saxatilis tissues. On the left side, brackets span the range between maximum and minimum predictions of Se tissue concentrations (see text). Circles are observed values for 13 juvenile fish and 15 adult fish collected from northern San Francisco Bay. On the right side, bars represent ratios of Se concentrations in different tissues in the experiments and in the field-collected samples. Error bars are $\pm 1 \mathrm{SD}$.

the values except for $\mathrm{Zn}$ exceed $3 \% \mathrm{~d}^{-1}$. Se in particular was excreted 2-9 times faster by Morone saxatilis juveniles than by Mytilus edulis $\left(2-5 \% \mathrm{~d}^{-1}\right)$, Dreissena polymorpha $(2 \%$ $\left.\mathrm{d}^{-1}\right)$, Macoma balthica $\left(3 \% \mathrm{~d}^{-1}\right)$, and Mercenaria mercenaria $\left(1 \% \mathrm{~d}^{-1}\right) . \mathrm{Ag}, \mathrm{Am}$, and, in particular, $\mathrm{Cd}$ also exhibited somewhat higher rates of excretion than typically observed for these elements in bivalves. The $\mathrm{k}_{\mathrm{ef}} \mathrm{s}$ for diverse metals in marine copepods range from 5 to $38 \% \mathrm{~d}^{-1}$, with values lowest for $\mathrm{Zn}\left(5-9 \% \mathrm{~d}^{-1}\right)$ and typically about $15-20 \% \mathrm{~d}^{-1}$ for Se, Cd, and Ag (Wang and Fisher 1998b).

Of the three elements for which we mapped distributions, the two that were most closely associated with gut tissues $(\mathrm{Cd}$ and $\mathrm{Se})$ also exhibited faster excretion rates. By contrast, $\mathrm{Zn}$ was actually less concentrated in the gut region than elsewhere and was at the same time characterized by barely detectable $\mathrm{k}_{\mathrm{ef}}$ values. High concentrations of $\mathrm{Cd}$ and $\mathrm{Se}$ in the gut and high excretion rates of these elements may indicate that the fish were actively detoxifying and excreting these elements. Thus, the distinction between the excretion rates for these elements in fish and bivalves may reflect differences in the efficiency and mechanism of detoxification. Alternatively, these elements, especially Se, may actually be preferentially associated with compounds that are involved in biochemical processes in the liver. Se is a required element in certain enzymes (e.g., glutathione peroxidase) that help catalyze the breakdown of superoxide radicals (Stadtman 1974). It can also immobilize toxic metals such as $\mathrm{Hg}$ and $\mathrm{Cd}$ into inactive inorganic granules (Martoja and Berry 1980).

Field observations of Se in 6-month-old juvenile striped bass tissues were within the range of predictions for 2month-old juveniles using kinetic modeling (Fig. 6). This result concurs with those for other organisms, suggesting that biokinetic models can predict trace element concentrations in animal tissues on a site-specific basis to within a narrow concentration range. The observed Se tissue concentrations in muscle of striped bass juveniles and adults are 
less than those that have led to lowered reproductive performance in adult $M$. saxatilis $\left(\sim 3 \mu \mathrm{g} \mathrm{g}^{-1}\right.$ dry wt in muscle tissue: Coughlin and Velte 1989). However, the observed values are within $50 \%$ of potentially toxic values, and the maximum predictions actually exceed the $3 \mu \mathrm{g} \mathrm{g}^{-1}$ threshold. Zooplankton Se tissue concentrations vary considerably over spatial and temporal time scales in San Francisco Bay (D. Purkerson et al. pers. comm.), possibly in response to changes in dissolved Se concentration or speciation, or shifting phytoplankton species composition and abundance. Moreover, growth and ingestion of larval and juvenile striped bass are likely to vary spatially and through time in a way that may affect Se tissue concentrations in these fish. A doubling of food consumption between a low-growth and a high-growth year has the potential to increase Se concentrations in juvenile striped bass muscle tissue by $88 \%$, presuming that conversion efficiency and Se food content remain constant. Consequently, there is a significant possibility of short-term or localized toxicity to larval M. saxatilis in this estuary.

Our results for Se assimilation and retention by fish suggest a greater importance of benthic clams over planktonic organisms in the transport of Se, and perhaps other trace elements, to the top levels of the estuarine food web. Se is predicted to biomagnify only marginally as it progresses up the estuarine planktonic food chain from algae to crustaceans and then to striped bass larvae. The zooplankton on which the fish fed in these experiments, although efficient at assimilating Se from food, excrete 16-19\% of their Se $\mathrm{d}^{-1}$ (Wang and Fisher 1998b). Measurements of Se accumulation by mysids fed crustacean zooplankton suggest that mysids concentrate Se by a factor of 1.1- to 1.4-fold more than their prey. Consequently, Se is not much more concentrated in the zooplankton or mysid prey of these fish than in the phytoplankton at the base of the food chain. When fish are growing quickly and eating a large amount, Se is predicted to concentrate in fish tissues only 1.4-fold above the concentrations in their crustacean prey. Under the opposite scenario Se concentration is actually predicted to be less than that of their food. The lack of a strong tendency for Se to be biomagnified by these fish is a result of their efficient growth, high excretion rates, and, to a lesser degree, their relatively low AEs.

By contrast, $\mathrm{Se}$ is more concentrated in the tissues of many filter-feeding bivalves than in their algal prey (Reinfelder et al. 1998). Recent data on Potamocorbula amurensis, an invasive bivalve that now dominates the benthos of San Francisco Bay, suggest that this organism is unusually efficient at concentrating Se from phytoplankton because of their high AEs and low efflux rates (Schlekat et al. 2000). Thus, predators of these bivalves, such as sturgeon or diving ducks, may be particularly susceptible to changes in Se loadings to the Bay. Moreover, the striking shift in organic carbon flux from the plankton to the benthos that has resulted from the invasion of San Francisco Bay by $P$. amurensis may have the ancillary effect of increasing the efficiency of Se transport up the food web. San Francisco Bay may be a good example of an ecosystem that has undergone an ecologically mediated change in susceptibility to contaminant effects.

\section{References}

Brown, J. J., A. Ehtisham, ANd D. O. Conover. 1998. Variation in larval growth rate among striped bass stocks from different latitudes. Trans. Am. Fish. Soc. 127: 598-610.

Conover, D. O., J. J. Brown, AND A. Ehtisham. 1997. Countergradient variation in growth of young striped bass (Morone saxatilis) from different latitudes. Can. J. Fish. Aquat. Sci. 54: 2401-2409.

Coughlin, D. J., AND J. S. Velte. 1989. Dietary toxicity of selenium-contaminated red shiners to striped bass. Trans. Am. Fish. Soc. 118: 400-408.

Cutter, G. A. 1989. The estuarine behavior of selenium in San Francisco Bay. Estuar. Coastal Shelf Sci. 28: 13-34.

Fisher, N. S., AND J. R. REINFELDER. 1991. Assimilation of selenium in the marine copepod Acartia tonsa studied with a radiotracer ratio method. Mar. Ecol. Prog. Ser. 70: 157-164.

, AND M. WENTE. 1993. The release of trace elements by dying marine phytoplankton. Deep-Sea Res. 40: 671-694.

, J. L. Teyssié, S. W. Fowler, and W. X. WANG. 1996. Accumulation and retention of metals in mussels from food and water: A comparison under field and laboratory conditions. Environ. Sci. Technol. 30: 3232-3242.

, I. Stupakoff, S. Sañudo-Wilhelmy, W. X. Wang, J. L. Teyssié, S. W. Fowler, AND J. CRusius. 2000. Trace metals in marine copepods: A field test of a bioaccumulation model coupled to laboratory uptake kinetics data. Mar. Ecol. Prog. Ser. 194: 211-218.

Guillard, R. R. L., AND J. H. RYTher. 1962. Studies of marine planktonic diatoms 1. Cyclotella nana Hustedt and Detonula confervacea (Cleve) Gran. Can. J. Microbiol. 8: 229-239.

Heubach, W., R. J. Toth, and A. M. McCready. 1963. Food of young-of-the-year striped bass (Roccus saxatilis) in the Sacramento-San Joaquin River system. Calif. Fish Game 49: 224239.

KenNish, M. J. 1996. Practical handbook of estuarine and marine pollution. CRC Press.

LANDRUM, P. F., H. LeE, AND M. J. Lydy. 1992. Toxicokinetics in aquatic systems - model comparisons and use in hazard assessment. Environ. Toxicol. Chem. 11: 1709-1725.

LAngston, W. J., AND S. K. SPENCE. 1995. Biological factors involved in metal concentrations observed in aquatic organisms, p. 407-478. In A. Tessier and D. R. Turner [eds.], Metal speciation and bioavailability in aquatic systems. Wiley.

LEMLY, A. D. 1982. Response of juvenile centrarchids to sublethal concentrations of waterborne selenium: I. Uptake, tissue distribution, and retention: Aquat. Toxicol. 2: 235-252.

. 1998. Pathology of selenium poisoning in fish, p. 281-296. In W. T. Frankenberger and R. A. Engberg [eds.], Environmental chemistry of selenium. Marcel-Dekker.

LuOMA, S. N. 1983. Bioavailability of trace metals to aquatic organisms-a review. Sci. Total Environ. 28: 1-22.

, C. Johns, N. S. Fisher, N. A. Steinberg, R. S. OremLAND, AND J. R. REINFELDER. 1992. Determination of selenium bioavailability to a benthic bivalve from particulate and solute pathways. Environ. Sci. Technol. 26: 485-491.

MARTOJA, R., AND J.-P. BERRY. 1980. Identification of tiemannite as a probable product of demthylation of mercury by selenium in cetaceans. Vie Millieu 30: 7-10.

Moore, C. M. 1988. Food habits, population dynamics, and bioenergetics of four predatory fish species in Smith Mountain Lake, Virginia. Ph.D. Dissertation, Virginia Polytechnic Institute and State University.

Pentreath, R. J. 1973a. The accumulation and retention of ${ }^{65} \mathrm{Zn}$ and ${ }^{54} \mathrm{Mn}$ by the plaice Pleuronectes platessa, L. J. Exp. Mar. Biol. Ecol. 12: 1-18. 
1973b. The accumulation and retention of ${ }^{59} \mathrm{Fe}$ and ${ }^{58} \mathrm{Co}$ by the plaice Pleuronectes platessa, L. J. Exp. Mar. Biol. Ecol. 12: $315-326$.

Presser, T. S. 1994. The Kesterson effect. Environ. Manag. 18: 437-454.

- M. A. Sylvester, AND W. H. Low. 1994. Bioaccumulation of selenium from natural geologic sources in western states and its potential consequences. Environ. Manag. 18: 423-436.

REINFELDER, J. R., AND N. S. FisheR. 1991. The assimilation of elements ingested by marine copepods. Science 251: 794-796.

$\longrightarrow$, AND — 1994. Retention of elements absorbed by juvenile fish (Menidia menidia, Menidia beryllina) from zooplankton prey. Limnol. Oceanogr. 39: 1783-1789.

—, W. X. Wang, S. N. LuOMA, And N. S. Fisher. 1997. Assimilation efficiencies and turnover rates of trace elements in marine bivalves: A comparison of oysters, clams and mussels. Mar. Biol. 129: 443-452.

S. N. LuOMA, J. W. Nichols, AND W.-X. WANG. 1998. Trace element trophic transfer in aquatic organisms: A critique of the kinetic model approach. Sci. Total Environ. 219: $117-135$.

Roditi, H. A., AND N. S. Fisher. 1999. Rates and routes of trace element uptake in zebra mussels. Limnol. Oceanogr. 44: 17301749 .

, AND S. A. SAÑudo-WiLhelmy. 2000. Field testing a metal bioaccumulation model for zebra mussels. Environ. Sci. Technol. 34: 2817-2825.

Schlekat, C. E., P. R. Dowdle, B.-G. Lee, S. N. Luoma, and R. S. OREMLAND. 2000. Bioavailability of particle-associated Se to the bivalve Potamocorbula amurensis. Environ. Sci. Technol. 34: 4504-4510.

StadtMan, T. C. 1974. Selenium biochemistry. Science 183: $915-$ 922.

Thomann, R. V. 1981. Equilibrium model of fate of microcontaminants in diverse aquatic food chains. Can. J. Fish. Aquat. Sci. 38: $280-296$.

Wagemann, R., E. Trebacz, G. Boila, and W. L. Lockhart. 1998. Methylmercury and total mercury in tissues of arctic marine mammals. Sci. Total Environ. 218: 19-31.

WANG, W. X., AND N. S. Fisher. 1998a. Accumulation of trace elements in a marine copepod. Limnol. Oceanogr. 43: 273283.

, AND — 1998b. Excretion of trace elements by marine copepods and their biovailability to diatoms. J. Mar. Res. 56: 713-729.

- AND S. N LUOMA 1996. Kinetic determination of trace element bioaccumulation in the mussel Mytilus edulis. Mar. Ecol. Prog. Ser. 140: 91-113.

Received: 7 June 2001 Accepted: 30 December 2001 Amended: 15 January 2002 